\title{
Clinical nursing competency assessment: a scoping review
}

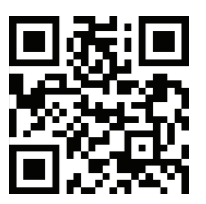

Review

\author{
Oboshie Anim-Boamah, Christmal Dela Christmals*, Susan Jennifer Armstrong \\ Department of Nursing Education, School of Therapeutic Sciences, Faculty of Health Sciences, University of Witwatersrand, \\ Johannesburg-Braamfontein, Gauteng 2050, South Africa
}

Received: 8 May 2021; Accepted: 7 June 2021; Published: 20 December 2021

\begin{abstract}
Objective: To ensure that only competent graduates are licensed to practice nursing, councils conduct licensing examinations, which may include among others clinical competency assessment. This review explored current practices in clinical competency assessment of nursing students as part of a larger study aimed at developing an evidence-based, context-specific framework for clinical competency assessment in a sub-Saharan African (SSA) country.

Methods: A scoping guided by the Preferred Reporting Items for Systematic reviews and Meta-Analyses extension for Scoping Reviews (PRISMA-ScR) was conducted.

Results: Findings from 28 out of 1151 studies identified from Scopus, PubMed, CINAHL, Wiley Online Library, and ProQuest were included and synthesized. Results show that a good assessment system must be valid, reliable, transparent, feasible, fair, objective, and must provide feedback and continually improve to have an educational impact. Clinical competency assessment systems must be developed on sound empirical evidence, pilot tested, and involve thorough training and evaluation of the examiners. Continuous evaluation of the assessment system is also essential to ensure the quality and relevance of the assessment system. Only one of the included studies was conducted in Africa.

Conclusions: The paucity of clinical competency assessment research in sub-Saharan Africa may lead to benchmarking assessment systems on research conducted outside the context. Sub-Saharan Africa has a set of circumstances that demand a context-specific clinical competency assessment framework to guide clinical competency assessment.
\end{abstract}

Keywords: clinical competency assessment • licensing examination • nursing • scoping review • sub-Saharan Africag

(c) Shanxi Medical Periodical Press.

\section{Introduction}

The International Council of Nurses (ICN) defines competence as the effective application of a combination of knowledge, skills, and judgment in practice. ${ }^{1}$ Nursing is a practice-based profession where clinical placement, teaching, and learning are essential for students to acquire the necessary competencies for professional practice. $^{2-4}$ To ensure that only competent graduates are licensed to practice, nursing councils conduct licensing examinations, which may comprise clinical competency

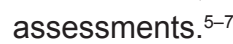

Assessment is the process of gathering and evaluating information on what an individual knows and

How to cite this article: Anim-Boamah O, Christmals CD, Armstrong SJ. Clinical nursing competency assessment: a scoping review. Front Nurs. 2021;4:341-356. 
he/she can do to make an informed decision about the next steps in the educational process or professional life..$^{8,9}$ In Nursing Education Institutions (NEIs), students' continuous and summative assessments in the three main domains of learning (cognitive, affective, and psychomotor) are conducted. ${ }^{10}$ Summative assessment in health profession educational programs aims to ensure that decisions such as progression and licensing, and prediction of future performance, are evidence-based. ${ }^{9}$ Assessment goes beyond an exercise that enables students to acquire a grade to pass a course; rather, a student may be required to use a combination of knowledge, skills, and attitudes that were learned in their theory and practice..$^{11-13}$

The importance of quality clinical assessment in nursing cannot be overemphasized as a proper assessment of clinical competence has a positive influence on patient care. ${ }^{14}$ Assessment is said to be of good quality if it is valid, fair, transparent, reliable, feasible, and has an educational impact. ${ }^{11,15}$ An assessment system should have the ability to accurately differentiate competent students from incompetent ones. ${ }^{16}$

In a recent review of nursing competency assessment in general, Reljić et al. ${ }^{17}$ stated that there are three main types of clinical competency assessment: observation, self-assessment, and a combination of both - the most common of all being the structured observation using rubrics. Reljić et al. ${ }^{17}$ concluded that notwithstanding the system, approach, and model or framework used for clinical competency assessment, it should measure knowledge, clinical skills, and problem-solving skills. Lastly, the review proposed further research to develop and validate a reliable clinical competency assessment tool (system). ${ }^{17}$ The purpose of this study is to explore current practices in clinical competency assessment of nursing students globally. This review forms part of a larger study aimed at developing an evidence-based, context-specific framework for clinical competency assessment in a sub-Saharan African (SSA) country.

\section{Methods}

\subsection{Design}

This scoping review was guided by the Preferred Reporting Items for Systematic reviews and Meta-Analyses extension for Scoping Reviews (PRISMA-ScR). ${ }^{18}$ Scoping reviews synthesize findings from empirical qualitative, quantitative and mixed-method studies. According to Christmals and Armstrong, ${ }^{19}$ scoping reviews are conducted either as pre-systematic or free-standing reviews to synthesize findings from empirical and gray literature on a complex concept. "Clinical competency assessment" is a complex concept, hence the choice of methodology.

\subsection{Search and inclusion}

Five databases, Scopus, PubMed, CINAHL, Wiley Online Library, and ProQuest, were searched using varying combinations of the keywords: (Nursing OR Clinical) AND (Competence OR skill OR performance) AND (assessment OR evaluation). Peer-reviewed literature published in English from 2014 to 2019 that meet the objective of the study were included. The studies identified were imported into the Mendeley reference manager group where all duplicates were removed. ${ }^{20,21}$ All titles were scanned, abstracts, where the study titles were related to the study objectives, were read, and full texts of the abstracts that met the inclusion criteria were retrieved by two independent reviewers. The two reviewers met and compared their list to reconcile their inclusion and exclusion decisions. There were no contentions on any study, hence there was no need for an adjudicator.

\subsubsection{Studies included}

The search produced 1151 studies from the databases. Thirty-nine (39) duplicates were identified and merged, leaving 1112 studies. After screening the titles of the 1112 remaining studies, 1063 were excluded leaving 49 studies. The full articles of the 49 studies left were retrieved and critically evaluated. Twenty-eight (28) studies were finally included in this review, comprising 18 quantitative studies, 4 qualitative studies, 3 mixed-method, and 3 multimethod studies (Figure 1).

Of the studies included, 13 (46.4\%) were conducted in Europe followed by the Middle East $(5,17.9 \%)$, Americas $(3,10.7 \%)$, Asia $(3,10.7 \%)$, Australia $(3,10.7 \%)$. Only one study (3.6\%) included was from Africa (Figure 2). Of the 28 papers, 19 either developed or validated a clinical assessment tool or model. Participants were mostly nursing students, while other studies included qualified nurses. Two of the studies ${ }^{16,22}$ neither included input from nursing students nor did they use data collected from them.

\subsection{Data charting and synthesis}

Data were extracted from studies using an adapted extraction sheet (Table 1) from De Souza and Carvalho. ${ }^{23}$ Author and setting, the aim of the study, methodology, data collection and analysis, and key 


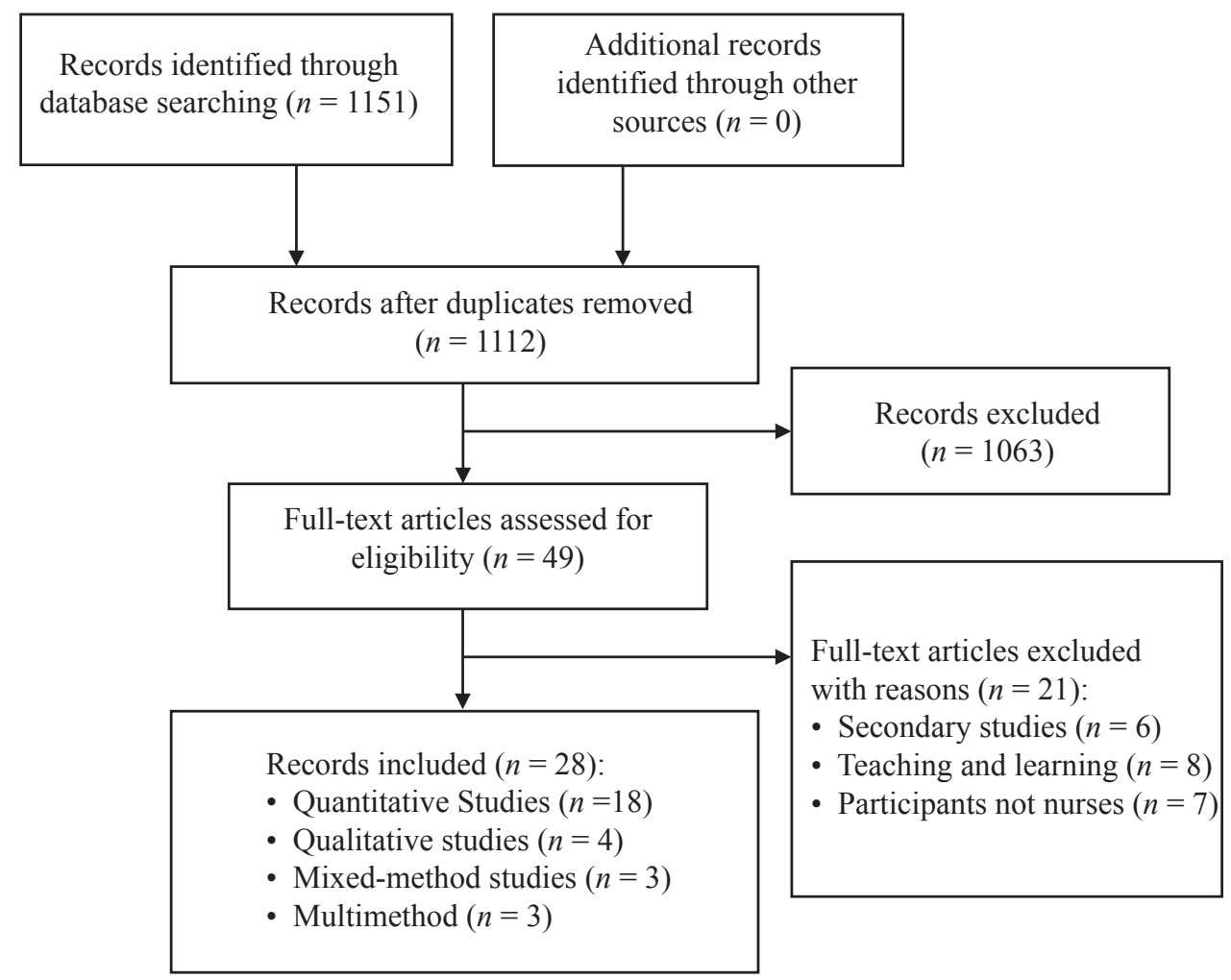

Figure 1. Search and inclusion process.

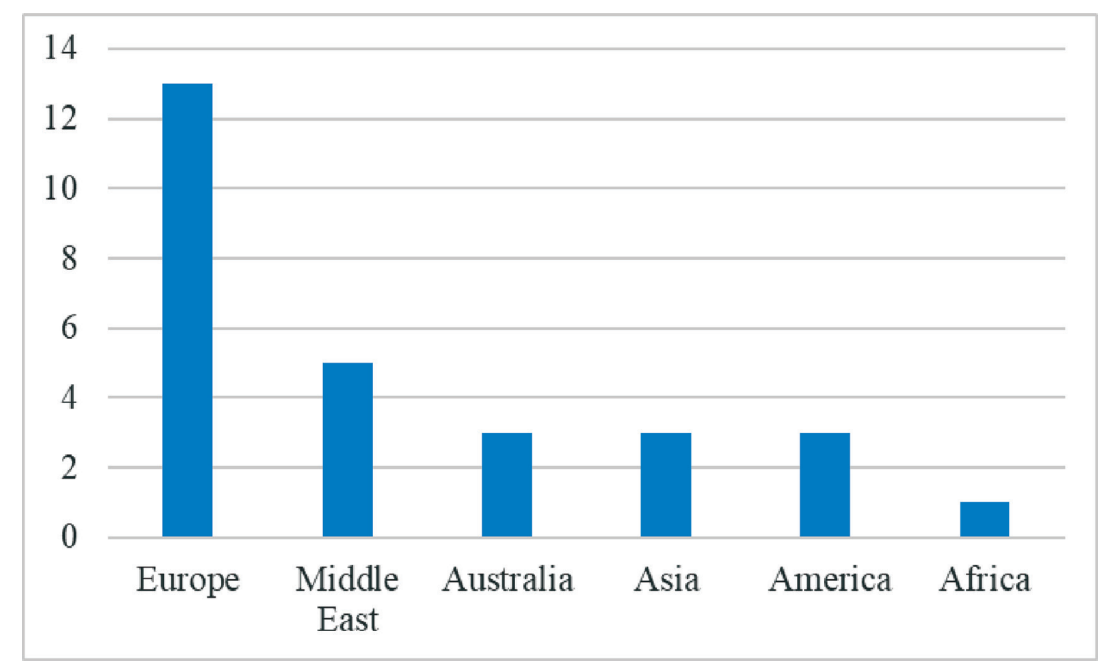

Figure 2. Distribution of papers included

findings were extracted. All the quantitative results were qualitized and synthesized with the qualitative data, using a convergent integrated approach. ${ }^{24}$ Data were synthesized using the five-stage data analysis method outlined by Whittemore and Knafl25: reduction, data display, data comparison, drawing of conclusions, and verification. ${ }^{2}$

\subsubsection{Quality appraisal}

The Joanna Briggs Institute (JBI) Critical Appraisal tools were used to evaluate the studies included in this study. The reviewers agreed that a study would be included if it met $80 \%$ of the criteria set in each of the JBI Critical Appraisal tools. ${ }^{50}$ All the included studies met the quality criteria for inclusion. 


\begin{tabular}{lll}
\hline $\begin{array}{l}\text { Author, country and } \\
\text { region }\end{array}$ & Aim of the study & $\begin{array}{l}\text { Data analysis, outcomes, } \\
\text { instruments }\end{array}$ \\
\hline \hline
\end{tabular}

Quantitative studies

included in the review

1. Ahn and Hyun-Young, To implement two high-fidelity Korea $^{26}$

2. Oetker-Black et al., Tanzania ${ }^{27}$

3. Teixeira et al., Brazil28

4. Alamri and Almazan Saudi Arabia ${ }^{29}$

5. Alquwez et al., Saudi Arabia ${ }^{14}$

6. Arbabshastan et al. Iran $^{30}$ students integrate their skills to evaluate the students simulations to help nursing cognitive and psychomotor simulation experience using the Simulation Design Scale and learning outcomes. To analyze the correlation between students' simulation experience and these learning outcomes.

To psychometrically evaluate the Clinical Skills Self-Efficacy Scale in a population of nursing students in Tanzania.

Psychometric evaluation. Quasi-experimental
post-test design. post-test design.

Five nursing experts and 69 nursin students ANCOVA was used to compare the experimental and control groups, and correlation coefficient analysis was used to determine the correlation among them.

287 nursing students enrolled in the preservice or in-service nursing programs at two schools Item analysis, reliability and validity were assessed.

CSES included 12 items in a confidence scale designed to measure clinical skills self-efficacy expectations
20 nursing students were randomly assigned to one of two groups.

The level of anxiety was assessed using the Zung test and on the number of correct answers. the traditional method of assessment with the presence of an evaluator and a filmed assessment without the presence of an evaluator.

To examine the barriers to physical assessment skills among nursing students in a government university in the Arab Peninsula.

Randomized control trial.

A cross-sectional research survey.

\section{A}

nursing students participated A standardized questionnaire was used.

Independent Samples t-test and paired t-test were used to analyze the data.

To assess the perceived patient safety competence during clinical training of Saudi nursing students. sectional design.

To determine the status of clinical competencies nurse practitioner students -self and instructor assessment. were used to analyze the data.
Analytical cross sectional study.

All senior nurse students ( $n=50)$ from a bachelor degree program. The checklist contained 16 items with Yes and No options and a selfassessment form to be completed after each competency. analyze data. performance was measured based Descriptive T-test was used to

Students rated guided reflection and fidelity highly in the designed simulations. Learning objectives were appropriate for third-year students Simulations led to higher self-confidence of students. Improved performance in course material may be achievable with the addition of rigorous simulation design.

Evidence of construct validity. Future research to focus on self-efficacy and the successful transferal of clinical skills learned in a simulated laboratory to the clinical setting.

The final scores of the two groups correspond to mild anxiety.

There was no difference between the groups.

Physical assessment is not often practiced in clinical settings.

Barriers identified were reliance on others and technology, ward culture, lack of influence on patient care.

Continuous exposure, increasing self-confidence and enhancing the quality of planning and promotion of the nursing students could help develop necessary skills.

Students expressed positive Descriptive and inferential statistics

perceptions toward their patient safety competencies. Significant differences in patient safety competence of nursing students between universities, gender, and year of study were recorded.

The lowest scores of competencies were from communication and hygiene The development of clinical competencies requires close mentorship from someone who can provide feedback to students. 


\begin{tabular}{|c|c|c|c|c|}
\hline $\begin{array}{l}\text { Author, country and } \\
\text { region }\end{array}$ & Aim of the study & Design & $\begin{array}{l}\text { Data analysis, outcomes, } \\
\text { instruments }\end{array}$ & Key findings \\
\hline 7. Daly et al., Australia ${ }^{16}$ & $\begin{array}{l}\text { To determine the extent } \\
\text { of assessor variability in } \\
\text { clinical skills assessments } \\
\text { in an undergraduate nursing } \\
\text { program. }\end{array}$ & $\begin{array}{l}\text { Prospective follow- } \\
\text { up study design }\end{array}$ & $\begin{array}{l}\text { The results of students' clinical } \\
\text { skills assessments in three clinical } \\
\text { units were extracted from an } \\
\text { administrative database. } \\
\text { Descriptive and inferential statistics } \\
\text { were used to analyze data. }\end{array}$ & $\begin{array}{l}\text { Overseas-born students } \\
\text { had lower pass grades than } \\
\text { Australian-born students. } \\
\text { Significant variability was seen } \\
\text { in pass grades across units, } \\
\text { campuses, and assessors. } \\
\text { Students assessed by the } \\
\text { most lenient assessors were } \\
\text { over seven times more likely to } \\
\text { pass than students assessed } \\
\text { by the most stringent } \\
\text { assessors. }\end{array}$ \\
\hline $\begin{array}{l}\text { 8. Gurkova et al., } \\
\text { Slovakia }^{31}\end{array}$ & $\begin{array}{l}\text { To investigate the use and } \\
\text { effectiveness of a valid } \\
\text { and reliable rating scale for } \\
\text { summative clinical evaluation } \\
\text { of student performance. }\end{array}$ & $\begin{array}{l}\text { Descriptive cross- } \\
\text { sectional study }\end{array}$ & $\begin{array}{l}82 \text { students participated in the } \\
\text { study. } \\
\text { Descriptive and inferential statistics. } \\
\text { This evaluation was compared with } \\
\text { the grade point for the students' } \\
\text { clinical performance obtained in the } \\
\text { practical component of their final } \\
\text { examinations. }\end{array}$ & $\begin{array}{l}\text { A valid and reliable tool may } \\
\text { allow an objective evaluation of } \\
\text { nursing student performance } \\
\text { in clinical settings. The Nursing } \\
\text { Student Clinical Performance } \\
\text { Evaluation Scale is useful } \\
\text { for summative evaluation of } \\
\text { student performance. Teachers } \\
\text { and clinical mentors can rate } \\
\text { students' performance over } \\
\text { time and note patterns of } \\
\text { performance. }\end{array}$ \\
\hline $\begin{array}{l}\text { 9. Iglesias-Parra et al., } \\
\text { Spain }^{32}\end{array}$ & $\begin{array}{l}\text { To develop an evaluation } \\
\text { system of clinical } \\
\text { competencies for the } \\
\text { practicum of nursing students } \\
\text { based on the NIC. }\end{array}$ & $\begin{array}{l}\text { Psychometric } \\
\text { validation study } \\
\text { a cross-sectional } \\
\text { study. }\end{array}$ & $\begin{array}{l}\text { Reliability and construct validity, as } \\
\text { well as responsiveness, were tested } \\
\text { by the evaluations performed by } \\
\text { clinical mentors on } 107 \text { students } \\
\text { over two consecutive years. } \\
12 \text { faculty staff and } 3 \text { clinical } \\
\text { lecturers participated in an expert } \\
\text { consensus panel using a modified } \\
\text { Delphi technique. }\end{array}$ & $\begin{array}{l}\text { A competency system for } \\
\text { the nursing practicum, } \\
\text { structured on the NIC, is a } \\
\text { reliable method for assessing } \\
\text { and evaluating clinical } \\
\text { competencies. }\end{array}$ \\
\hline $\begin{array}{l}\text { 10. Kajander et al., } \\
\text { Finland }^{33}\end{array}$ & $\begin{array}{l}\text { To assess the congruence } \\
\text { between graduating nursing } \\
\text { students' self-assessment and } \\
\text { their mentors' assessments } \\
\text { concerning nurse competence } \\
\text { with a particular focus on } \\
\text { nursing skills. }\end{array}$ & $\begin{array}{l}\text { Cross-sectional } \\
\text { study }\end{array}$ & $\begin{array}{l}\text { Completed questionnaires were } \\
\text { received from } 60 \text { students and } 50 \\
\text { mentors. } \\
42 \text { students-mentor pairs were } \\
\text { matched for the sample of this } \\
\text { study. } \\
\text { Descriptive and inferential statistics } \\
\text { were used in the data analysis. }\end{array}$ & $\begin{array}{l}\text { Students' rated their } \\
\text { performance higher than the } \\
\text { mentors. } \\
\text { No congruence assessments } \\
\text { were found between students } \\
\text { and mentors. }\end{array}$ \\
\hline $\begin{array}{l}\text { 11. Langari et al. } \\
\text { Finland and the } \\
\text { United Kingdom }\end{array}$ & $\begin{array}{l}\text { To examine and compare the } \\
\text { self-assessment of patient } \\
\text { safety competence between } \\
\text { British and Finnish nursing } \\
\text { students. }\end{array}$ & $\begin{array}{l}\text { Cross-sectional } \\
\text { study. }\end{array}$ & $\begin{array}{l}\text { The PaSNEQ, } 502 \text { surveys to the } \\
\text { final year nursing students } \\
\text { The data were analyzed with } \\
\text { descriptive statistics and binary } \\
\text { logistic regression. }\end{array}$ & $\begin{array}{l}\text { No separate module for } \\
\text { patient safety was included in } \\
\text { the curriculum. Both groups } \\
\text { of students ranked their } \\
\text { competence to prevent patient } \\
\text { safety incidents (attitude) the } \\
\text { highest and their competence } \\
\text { to act after errors (skill) } \\
\text { relatively low. }\end{array}$ \\
\hline $\begin{array}{l}\text { 12. Macia-Soler et al., } \\
\text { Spain }^{35}\end{array}$ & $\begin{array}{l}\text { To determine the level of } \\
\text { involvement of clinical nurses } \\
\text { accredited by the Universitat } \\
\text { Jaume I (Spain) as mentors of } \\
\text { practice (Reference Nurses) in } \\
\text { the evaluation of competence } \\
\text { of nursing students. }\end{array}$ & $\begin{array}{l}\text { Cross-sectional } \\
\text { study }\end{array}$ & $\begin{array}{l}200 \text { clinical nurses completed the } \\
\text { CPAM tool. }\end{array}$ & $\begin{array}{l}63 \% \text { of CPAM were completed } \\
\text { correctly, without reaching the } \\
\text { quality threshold established } \\
\text { ( } 80 \%) \text {. Nurses' performance on } \\
\text { the CPAM tool was determined } \\
\text { by their respective clinical } \\
\text { units There are significant } \\
\text { differences according to } \\
\text { clinical units. Collaboration and } \\
\text { training of clinical nurses was } \\
\text { recommended. }\end{array}$ \\
\hline
\end{tabular}

(Continued) 


\begin{tabular}{llll}
\hline $\begin{array}{l}\text { Author, country and } \\
\text { region }\end{array}$ & Aim of the study & Design & $\begin{array}{l}\text { Data analysis, outcomes, } \\
\text { instruments }\end{array}$ \\
\hline \hline $\begin{array}{lll}\text { 13. Murray et al., } \\
\text { United Kingdom }\end{array}$ & $\begin{array}{l}\text { An evaluation of a NTS } \\
\text { framework that could } \\
\text { potentially be used to measure } \\
\text { ward round skills of student } \\
\text { nurses. }\end{array}$ & $\begin{array}{l}\text { Observation } \\
\text { (cohort) study. }\end{array}$ & $\begin{array}{l}\text { Development of NTS framework } \\
\text { Rating of simulation using } \\
\text { framework. }\end{array}$ \\
& & $\begin{array}{l}\text { Evaluating content validity of } \\
\text { framework. }\end{array}$
\end{tabular}

14. Numminen et al., Finland $^{37}$ Ireland ${ }^{38}$

16. Oermann et al., United States of America $^{39}$
15. Meskell et al.,
To evaluate whether educational outcomes of nurse education meet the requirements of nursing practice by exploring the correspondence between nurse educators' and nurse managers' assessments of novice nurses' professional competence.

To explore electronic OSCE delivery and evaluate the benefits of using an electronic OSCE management system. To explore assessors perceptions of and attitudes to the computer-based package.

To explore the feasibility of developing scenarios for highstakes evaluation of students' clinical performance.
A cross-sectional, 86 Nurse educators and 141 nurse comparative design managers.

using the Nurse Descriptive and inferential statistics Competence Scale. were used in the data analysis
A descriptive survey.
An electronic software in the management of a four-station OSCE assessment with first-year nursing students over two consecutive years $(n=203)$

Assessors were trained in the use of the OSCE management software package

Assessors were invited to evaluate their experience.

Video recordings of students performing in standardized scenarios.

Four outcomes were chosen for the evaluation of students' clinical performance in a simulation based on the results of an expert panel think tank

(a) assessment and intervention,

(b) nursing judgment,

(c) quality and safety, and

(d) teamwork and collaboration Communication was integrated across other areas.

17. Ossenberg et al., Australia ${ }^{40}$

18. Solheim et al., Norway ${ }^{41}$
To advance the assessment Cross-section properties of a new instrument, survey study the ANSAT, and investigate the acceptability of this instrument when applied to the evaluation of the professional competence of nursing students in authentic practice settings.

To develop and evaluate a new Descriptive design reflection and feedback tool for formative assessment.
A validation study of ANSAT was conducted by 23 clinical assessors from two universities, completing 220 instruments for nursing students.

Data were analyzed using both descriptive and inferential statistics.

129 nursing students participated in the study. After high fidelity simulation, data were collected using a questionnaire with 19 closed-ended and 2 open-ended questions.
Key findings

The proposed NTS framework included seven categories which were rated as important and relevant to practice and could be used as a means of evaluating student nurse competencies in respect of many NTS required for a successful ward round.

Examiners who are educators rate novice nurses' competence higher than examiners who are managers in all competence areas. Differences between educators' and managers' assessments scores were strongly associated with their age and work experience.

Electronic software facilitated

the storage and analysis of overall group and individual results thereby offering considerable time savings. Submission of electronic forms was allowed only when fully completed thus removing the potential for missing data. Students were able to compare their performance with the class due to the timely feedback of the software.

Most of the nursing students were able to competently perform most of the skills assessed on the CCEI. There was some inconsistency in the inter-rater agreement. Administering medications safely; managing technology and equipment; and performing procedures were items that generated the most inter-rater disagreement while patient safety recorded lower inter-rater disagreement. Checking the functionality of the equipment.

The instrument is sensitive to different levels of performance across different year levels. The ANSAT has high internal consistency. With the addition of supportive behavioral cues, the ANSAT enables clarity, consistency, and collaboration in the workplace-based assessment.

The tool provided a structure for self-assessment and made visible items that are important to be aware of in clinical skills. The tool has the potential for enabling students to learn about reflection and developing skills for guiding others in practice after they have graduated. 


\begin{tabular}{|c|c|c|c|c|}
\hline $\begin{array}{l}\text { Author, country and } \\
\text { region }\end{array}$ & Aim of the study & Design & $\begin{array}{l}\text { Data analysis, outcomes, } \\
\text { instruments }\end{array}$ & Key findings \\
\hline
\end{tabular}

Qualitative studies

19. Cassidy et al., United Kingdom ${ }^{42}$

20. Meier et al., United Kingdom ${ }^{22}$

21. Ochylski et al., United States of America $^{43}$

22. Tommasini et al. Belgium, Denmark, Greece, Norway, Poland, Portugal, and Italy ${ }^{44}$

competence assessment To examine how the ISP was used to assess interpersonal skills in a university preregistration nursing program.

To demonstrate the use of a multidimensional evaluation method as applied to a new simulation-based remediation course to enhance the clinical skills of prelicensure nursing students. adopted for nursing students during their clinical placement abroad.

Mixed method

23. Burke et al., Ireland ${ }^{45}$

To explore Irish preceptors' experience of using a

24. Zasadny et al., Australia ${ }^{13}$

Grounded theory Interviews and focus group study.

Realistic evaluation Interviews with clinical nursing approach mentors, practice education

A case study design mer discussions with Registered Nurse mentors and practice educators. Data were analyzed using open, axial, and selective coding consistent. facilitators, and education champions. Documentary analysis of student assessment booklets was also done.

Seven who participated in a variety of simulation scenarios and skillbuilding activities were interviewed on the last day using 12 openended questions.
Tools for evaluating competences and written procedures were scrutinized through a content analysis method. Seven European countries participated in the study.
There were conflicts regarding mentors' assessment decisionmaking where students were on the borderline of achievement of competence in clinical practice. The need to prepare, support, and regulate nurses who assess the clinical competency of nursing students.

The ISP tool is used for formative and summative assessment. It supports the overt assessment of interpersonal skills, support to mentors, and provides feedback and "feed-forward" to students.

Student scores reflected positive skill performance 2 months after participating in the course. Some students expressed concern over a potential negative stigma among peers for needing and participating in a skills enhancement course.

Great variability emerged in the tools, with between five and 88 items included. Twelve different core competence categories were identified. Increased transparency in learning expectations and evaluation.

Six focus group interviews to explore Preceptors had difficulty preceptor's experience of using an understanding the content collected from students and clinical facilitators. competence tool to assess undergraduate nursing students' clinical competence. assessment tool to assess clinical competence.

A descriptive survey instrument was developed and administered to 843 preceptors to measure preceptor's attitudes to the local competence assessment tool.

The ASAP tool was trialed in three public tertiary hospitals and four private hospitals. Quantitative and qualitative feedback was

of the tool as it was too academic. Challenges of using the assessment too include difficulty understanding the content, negotiating complex repetitive language, time constraints and the need to facilitate qualitative commentary. response to the inadequacies of existing tools to assess competence.
The ASAP model can be used as a focused diagnostic tool, removal from PEP support tool, and a framework for documenting evidence. The ASAP model offers a comprehensive focused assessment of nursing students' performance in practice. It supports both formative and summative feedback and can be used to accurately identify specific areas of practice deficiency requiring redirection and support for nursing students. 


\begin{tabular}{|c|c|c|c|c|}
\hline $\begin{array}{l}\text { Author, country and } \\
\text { region }\end{array}$ & Aim of the study & Design & $\begin{array}{l}\text { Data analysis, outcomes, } \\
\text { instruments }\end{array}$ & Key findings \\
\hline 25. Lai, Taiwan, China ${ }^{46}$ & $\begin{array}{l}\text { To implement an online video } \\
\text { peer assessment system to } \\
\text { scaffold their communication } \\
\text { skills and examine the effects } \\
\text { and validity of the peer } \\
\text { assessment. }\end{array}$ & & $\begin{array}{l}\text { Expert evaluation scores showed } \\
\text { that peer assessments led to } \\
\text { significant improvement in students' } \\
\text { communication performance. }\end{array}$ & $\begin{array}{l}\text { Online peer assessment } \\
\text { could be perceived as a } \\
\text { valid assessment method } \\
\text { for nursing communication } \\
\text { skills training. Communication } \\
\text { became more patient- } \\
\text { centered gradually due to } \\
\text { peer assessments. Peer } \\
\text { assessment activities } \\
\text { contributed to the improvement } \\
\text { of the communication skills of } \\
\text { students }\end{array}$ \\
\hline \multicolumn{5}{|l|}{ Multimethod } \\
\hline $\begin{array}{l}\text { 26. Marquez-Henandez } \\
\text { et al., Spain }{ }^{47}\end{array}$ & $\begin{array}{l}\text { To design, develop, and } \\
\text { implement a tool to evaluate } \\
\text { the clinical skills of nursing } \\
\text { students. }\end{array}$ & & $\begin{array}{l}250 \text { Nursing students were } \\
\text { randomly placed in an experimental } \\
\text { group and a control group. } \\
\text { Descriptive analysis was conducted, } \\
\text { the nonparametric Mann Whitney } \\
\cup \text { test was used to compare } \\
\text { the qualitative and quantitative } \\
\text { variables. }\end{array}$ & $\begin{array}{l}\text { The web-based tool designed } \\
\text { is an effective strategy to } \\
\text { evaluate clinical skills. The } \\
\text { need for innovative strategies } \\
\text { that can determine the } \\
\text { development and acquisition } \\
\text { of the skills required for future } \\
\text { nursing professional }\end{array}$ \\
\hline $\begin{array}{l}\text { 27. Imanipour and } \\
\text { Jalili, } / \operatorname{ran}^{48}\end{array}$ & $\begin{array}{l}\text { To develop a comprehensive } \\
\text { assessment system for } \\
\text { nursing students in their critical } \\
\text { care rotation based on a } \\
\text { programmatic approach }\end{array}$ & $\begin{array}{l}\text {-Expert review } \\
\text {-Quantitative study }\end{array}$ & $\begin{array}{l}38 \text { nursing students in their critical } \\
\text { care course. } \\
\text { The learning objectives of the } \\
\text { course were classified into three } \\
\text { categories using an expert panel } \\
\text { content validity and reliability of the } \\
\text { assessment tools were established }\end{array}$ & $\begin{array}{l}\text { The new assessment system } \\
\text { had high validity, reliability, and } \\
\text { a positive impact on learning. } \\
\text { A programmatic approach } \\
\text { should be used for the } \\
\text { effective evaluation of the } \\
\text { clinical performance of nursing } \\
\text { students in critical care } \\
\text { settings. }\end{array}$ \\
\hline $\begin{array}{l}\text { 28. Wu et al., } \\
\text { Singapore }\end{array}$ & $\begin{array}{l}\text { To develop and test } \\
\text { psychometric properties of a } \\
\text { holistic clinical assessment }\end{array}$ & $\begin{array}{l}\text {-Systematic review } \\
\text {-Expert review } \\
\text {-Student survey }\end{array}$ & $\begin{array}{l}\text { Synthesis of the literature, } \\
\text { exploratory and confirmatory factor } \\
\text { analysis, Content Validity Index }\end{array}$ & $\begin{array}{l}\text { HCAT was developed } \\
\text { and validated through } \\
\text { psychometric testing. The tool } \\
\text { was internally consistent and } \\
\text { reliable. }\end{array}$ \\
\hline
\end{tabular}

ASAP, Australian amalgamated student assessment in practice; ANSAT, Australian Nursing Standards Assessment Tool; CPAM, Clinical Practice Assessment Manual; CCEI, Creighton Competency Evaluation Instruments; HCAT, Holistic Clinical Assessment Tool; ISP, Interpersonal Skills Profile NTS, Non-Technical Skills; NIC, Nursing Interventions Classification; PaSNEQ, Patient Safety in Nursing Education Questionnaire; PEP, Professional Experience Placement.

Table 1. Data matrix.

\section{Results}

Data were synthesized into five categories namely: clinical competency systems and tools; qualities of the assessment Systems/Tools/Frameworks/Models; strengths and weaknesses of the assessment process; management of assessment process; and quality improvement of the examination system. Sub-categories were also presented below.

\subsection{Clinical competency assessment tools}

The tools used in the included studies were developed either to assess technical skills or non-technical skills (NTS). Technical skills include: patient assessment ${ }^{13}$; nursing care process ${ }^{31,44}$; managing patient care and education $^{44}$; wound dressing ${ }^{48,51}$; catheterization ${ }^{41,47,48,51}$; inserting feeding tube ${ }^{41}$; inserting a nasogastric tube ${ }^{51}$; preparation and administration of parenteral medication $^{41,47}$; handwashing ${ }^{38}$; documentation ${ }^{38}$; blood sampling $^{48}$; inserting peripheral lines ${ }^{41}$ and management of care. ${ }^{49}$

NTS that were assessed included: self-learning and critical thinking ${ }^{44}$; interpersonal skills ${ }^{22}$; ethical behavior $^{44}$; nurse-patient communication ${ }^{36,44}$; risk prevention ${ }^{44}$; nursing students' communication performance on advocacy, the therapeutic use of self and validation to patients and family ${ }^{46}$; and ethical principles and professionalism. ${ }^{31}$

The studies presenting the tools in Table 2 were mainly focused on the assessment of clinical competency skills ${ }^{29}$; preceptor experience of using competency tools ${ }^{45}$; anxiety level of students during the assessment ${ }^{28}$; assessment practices of nurse educators and managers ${ }^{37}$; involvement of clinical nurses as mentors ${ }^{35}$; mentors experiences when nursing students are on the 
borderline of achievement of competence in clinical practice. ${ }^{42}$ Other areas included comparing nursing students' self-assessment and mentors' assessments on competency skills ${ }^{33}$; and influence of assessors, ${ }^{16}$ professional, legal and ethical nursing practice, leadership and nursing management and professional development. ${ }^{49}$

\subsection{Qualities of assessment systems/tools/ frameworks/models}

Quality assessment tools/systems/frameworks should have the following features: objectivity and feasibility 22,48 ; educational impact ${ }^{45,48}$; validity and reliability $22,26,31,32,38,40,49,51$; defined scope ${ }^{13}$; defined procedures ${ }^{44}$; measuring dimensionality of the tool ${ }^{51}$; utility of the tool ${ }^{22,40}$; transparency and clarity ${ }^{22,44,49}$; relevance ${ }^{40,49}$; efficient/timely to complete ${ }^{40}$; data storage ${ }^{38}$; support reflection $^{41,49}$ and provide feedback (Figure 3). ${ }^{13,22,31,39,41,45,46,48,49}$

\subsection{Strengths and weaknesses of the assessment process}

Strengths and weaknesses were identified in the clinical competency assessment systems. The authors identified improved self-confidence ${ }^{26}$; critical thinking $^{26}$ and good communication ${ }^{34,43,46}$; collaboration and teamwork $^{43,46}$; effective remediation ${ }^{35}$; quality nursing care $^{29}$ and monitoring students' progress ${ }^{49}$ as strengths of assessment systems. Using different evaluation forms ${ }^{44}$; incongruence between teaching and assessment ${ }^{22}$; no module on patient safety in the curriculum ${ }^{34}$; overwhelming clinical scenarios ${ }^{39}$; and difficulty with face-to-face interaction ${ }^{22}$ and lengthy assessment tool ${ }^{49}$ were identified as weaknesses in clinical competency assessment.

\subsection{How the assessment system should be managed}

Findings from the synthesis outlined some aspects (subcategories) of managing the assessment processes, such as testing assessment tools, examiner-related factors, supporting students, scoring performances, and educational effects that are critical for a quality clinical competency assessment.

\subsubsection{Pilot testing of the assessment system}

Before commencing a clinical competency examination, there is a need to conduct a pilot test of the assessment tools and scenarios in the examination setting. Pilot testing helps correct any errors regarding scenarios ${ }^{39}$ and

\begin{tabular}{|c|c|c|c|c|c|}
\hline Tools & Purpose & Development & Validated & Publicly available & Remarks \\
\hline The ISP $^{22}$ & $\begin{array}{l}\text { To assess students } \\
\text { interpersonal and } \\
\text { professional skills }\end{array}$ & $\begin{array}{l}\text { It comprises } 40 \text { statements } \\
\text { about interpersonal skills, } \\
\text { professionalism, and } \\
\text { engagement with the learning } \\
\text { process, against which students' } \\
\text { performance in practice may be } \\
\text { graded }\end{array}$ & Yes & Yes & $\begin{array}{l}\text { Can be used for } \\
\text { both formative } \\
\text { and summative } \\
\text { assessment }\end{array}$ \\
\hline QLCCT $^{27}$ & $\begin{array}{l}\text { To assess formative and } \\
\text { summative competency } \\
\text { skills of students based on } \\
\text { Tanners (2006) model. }\end{array}$ & $\begin{array}{l}\text { The tool, which is grounded in } \\
\text { the seminal work of Tanner, }{ }^{52} \\
\text { consists of } 8 \text { items on which } \\
\text { students are rated either } \\
\text { as a novice, progressing, } \\
\text { advancing, or a graduate } \\
\text { nurse. Psychometric properties } \\
\text { of the tool were reported as } \\
\text { interrater reliability }(0.87) \text {, content } \\
\text { validity index }(0.72), \text { and alpha } \\
\text { coefficient }(0.83)\end{array}$ & Yes & Yes & $\begin{array}{l}\text { The tool provides } \\
\text { a clear and reliable } \\
\text { way of measuring the } \\
\text { clinical competency } \\
\text { of students at various } \\
\text { stages of training }\end{array}$ \\
\hline $\begin{array}{l}\text { ENS Assessment } \\
\text { tools ENS }{ }^{44}\end{array}$ & $\begin{array}{l}\text { To compare the clinical } \\
\text { competence assessment } \\
\text { processes and instruments } \\
\text { adopted for nursing students } \\
\text { during their clinical placement } \\
\text { abroad }\end{array}$ & $\begin{array}{l}\text { The tool composes } 196 \text { items } \\
\text { which were categorized into 12: } \\
\text { "Technical skills competence; } \\
\text { Self-learning and critical thinking; } \\
\text { Nursing care process; } \\
\text { Ethical behavior; Patient } \\
\text { communication; Risk prevention' } \\
\text { competence category; } \\
\text { Self-adaptation; Clinical } \\
\text { documentation; Managing } \\
\text { nursing care; Patient/family } \\
\text { education; and Theory and } \\
\text { practice integration" }\end{array}$ & Yes & Not applicable & $\begin{array}{l}\text { Increases } \\
\text { transparency in } \\
\text { learning expectations } \\
\text { and evaluation }\end{array}$ \\
\hline
\end{tabular}




\begin{tabular}{|c|c|c|c|c|c|}
\hline Tools & Purpose & Development & Validated & Publicly available & Remarks \\
\hline $\begin{array}{l}\text { ASAP tool- } \\
\text { amalgamated } \\
\text { student } \\
\text { assessment in } \\
\text { practice model }{ }^{13}\end{array}$ & $\begin{array}{l}\text { The ASAP model } \\
\text { functioned effectively } \\
\text { as an assessment tool, } \\
\text { focused diagnostic tool, } \\
\text { removal from PEP support } \\
\text { tool, and a framework for } \\
\text { documenting evidence }\end{array}$ & $\begin{array}{l}\text { The model comprises an } \\
\text { assessment tool, a clinical } \\
\text { reasoning framework and a } \\
\text { negotiated learning contract. } \\
\text { The tool assesses developing } \\
\text { competence into levels of safe, } \\
\text { safe and effective, and lastly } \\
\text { safe, effective and proficient. } \\
\text { These levels of competence } \\
\text { development are applied to } \\
\text { each of the components of } \\
\text { competence: knowledge, skills, } \\
\text { and attitudes/behaviors }\end{array}$ & Yes & Yes & $\begin{array}{l}\text { It is useful for both } \\
\text { formative and summative } \\
\text { assessment }\end{array}$ \\
\hline ICAS tool ${ }^{53}$ & $\begin{array}{l}\text { To assess the } \\
\text { communication } \\
\text { competencies of students } \\
\text { in undergraduate programs }\end{array}$ & $\begin{array}{l}\text { This tool is a } 23 \text { items tool. } \\
\text { Psychometric testing produces a } \\
\text { Cronbach's alpha of } 0.96 \text {. }\end{array}$ & Yes & Yes & $\begin{array}{l}\text { Used for summative and } \\
\text { formative assessment } \\
\text { clinical performance }\end{array}$ \\
\hline H-PEPSS ${ }^{54}$ & $\begin{array}{l}\text { To assess patient safety } \\
\text { competencies of students }\end{array}$ & $\begin{array}{l}\text { Six domains of the safety } \\
\text { competencies: "Contribute to a } \\
\text { culture of patient safety; Work } \\
\text { in teams for patient safety; } \\
\text { Communicate effectively for } \\
\text { patient safety; Manage safety } \\
\text { risks; Optimise human and } \\
\text { environmental factors; and } \\
\text { Recognise, respond to and } \\
\text { disclose adverse events" }\end{array}$ & Yes & Yes & $\begin{array}{l}\text { It is an effective tool in } \\
\text { assessing summative } \\
\text { clinical performance }\end{array}$ \\
\hline NSCPES ${ }^{31}$ & $\begin{array}{l}\text { To assess the summative } \\
\text { clinical performance of } \\
\text { nursing students }\end{array}$ & $\begin{array}{l}\text { Instrument development } \\
\text { consists of } 77 \text { items of clinical } \\
\text { responsibilities of nursing } \\
\text { students. }\end{array}$ & Yes & Yes & $\begin{array}{l}\text { A valid and reliable tool } \\
\text { may allow an objective } \\
\text { evaluation of Nursing } \\
\text { students' performance in } \\
\text { clinical settings. }\end{array}$ \\
\hline DOPS $^{55}$ & $\begin{array}{l}\text { To assess students clinical } \\
\text { performance through direct } \\
\text { observation }\end{array}$ & $\begin{array}{l}\text { Many variant forms of tools are in } \\
\text { use. Khanghahi and Azar (2018) } \\
\text { presented a systematic review of } \\
\text { the DOPS used. }\end{array}$ & Not applicable & Not applicable & $\begin{array}{l}\text { Insufficient training, } \\
\text { poor feedback, time } \\
\text { constraints. Attention } \\
\text { needs to be paid to the } \\
\text { quality of the tests }\end{array}$ \\
\hline NTS-NAS ${ }^{56}$ & $\begin{array}{l}\text { To assess the not technical } \\
\text { skills of nursing students }\end{array}$ & $\begin{array}{l}\text { NTS-NAS resulted in a list of } \\
63 \text { items that are assessed on } \\
\text { a 5-point Likert scale: "totally } \\
\text { disagree to totally agree" } \\
\text { with intermediaries. A "non- } \\
\text { applicable" option was also } \\
\text { added. }\end{array}$ & Yes & Yes & $\begin{array}{l}\text { This tool could be used in } \\
\text { teaching and assessment } \\
\text { in undergraduate and } \\
\text { postgraduate programs }\end{array}$ \\
\hline CCEI $\left.\right|^{57}$ & $\begin{array}{l}\text { To assess clinical } \\
\text { competency of nursing } \\
\text { students in simulation or } \\
\text { traditional clinical settings }\end{array}$ & $\begin{array}{l}\text { The tool focuses on } 22 \text { general } \\
\text { nursing behaviors which were } \\
\text { divided into four categories: } \\
\text { "assessment, communication, } \\
\text { clinical judgment, and patient } \\
\text { safety". }\end{array}$ & Yes & Yes & $\begin{array}{l}\text { This tool has been } \\
\text { validated and is used } \\
\text { in many countries }\end{array}$ \\
\hline ANSAT $^{40}$ & $\begin{array}{l}\text { The instrument tested } \\
\text { contained } 17 \text { items spread } \\
\text { across } 4 \text { domains of } \\
\text { practice used to assess } \\
\text { the student's level of ability. } \\
\text { The items are rated using a }\end{array}$ & $\begin{array}{l}\text { A } 17 \text { item tool which is rated } \\
\text { on a } 1-4 \text { scale. The tool is } \\
\text { categorized into } 4 \text { domains: } \\
\text { "professional practice; critical } \\
\text { thinking and analysis; provision } \\
\text { and coordination of care; and } \\
\text { collaborative and therapeutic } \\
\text { practice". The scale is calibrated } \\
\text { as: "1 = minimum standards not } \\
\text { met, } 2=\text { minimum standards } \\
\text { met, } 3=\text { performs above } \\
\text { minimum standards in some } \\
\text { areas, } 4=\text { performs above } \\
\text { minimum standards in most } \\
\text { areas". }\end{array}$ & Yes & Yes & $\begin{array}{l}\text { It allows for clarity, } \\
\text { reliability, and } \\
\text { collaboration in clinical } \\
\text { competency assessment }\end{array}$ \\
\hline
\end{tabular}




\begin{tabular}{|c|c|c|c|c|c|}
\hline Tools & Purpose & Development & Validated & Publicly available & Remarks \\
\hline $\mathrm{COPP}^{41}$ & $\begin{array}{l}\text { It is intended to help } \\
\text { students in their formative } \\
\text { assessment and reflection } \\
\text { on themselves and their } \\
\text { peers before, during, and } \\
\text { after learning clinical skills. }\end{array}$ & $\begin{array}{l}\text { Measures five main areas: } \\
\text { "Preparation and planning, } \\
\text { Performance } \\
\text { Supplementary work, Overall } \\
\text { assessment, and Knowledge on } \\
\text { clinical skills" }\end{array}$ & Yes & Yes & $\begin{array}{l}\text { The tool provided } \\
\text { a structure for self- } \\
\text { assessment indicates } \\
\text { essential components of } \\
\text { skills for students }\end{array}$ \\
\hline
\end{tabular}

ASAP, Australian amalgamated student assessment in practice; ANSAT, Australian Nursing Standards Assessment Tool; COPP, Competencedevelopment of Practical Procedures; CEEI, Creighton Competency Evaluation Instruments; DOPS, Direct observation of procedural skills; ENS, Erasmus Nursing Students; H-PEPSS, Health Professional Education in Patient Safety Survey; ICAS, Interpersonal Communication Assessment Scale; ISP, Interpersonal Skills Profile; NTS-NAS, Non-Technical Skills - Nursing Assessment Scale; NSCPES, Nursing Students Clinical Performance Evaluation Scale; PEP, Professional Experience Placement; QLCCT, Quint Leveled Clinical Competency Tool.

Table 2. Clinical competency assessment systems/tools/frameworks/models.

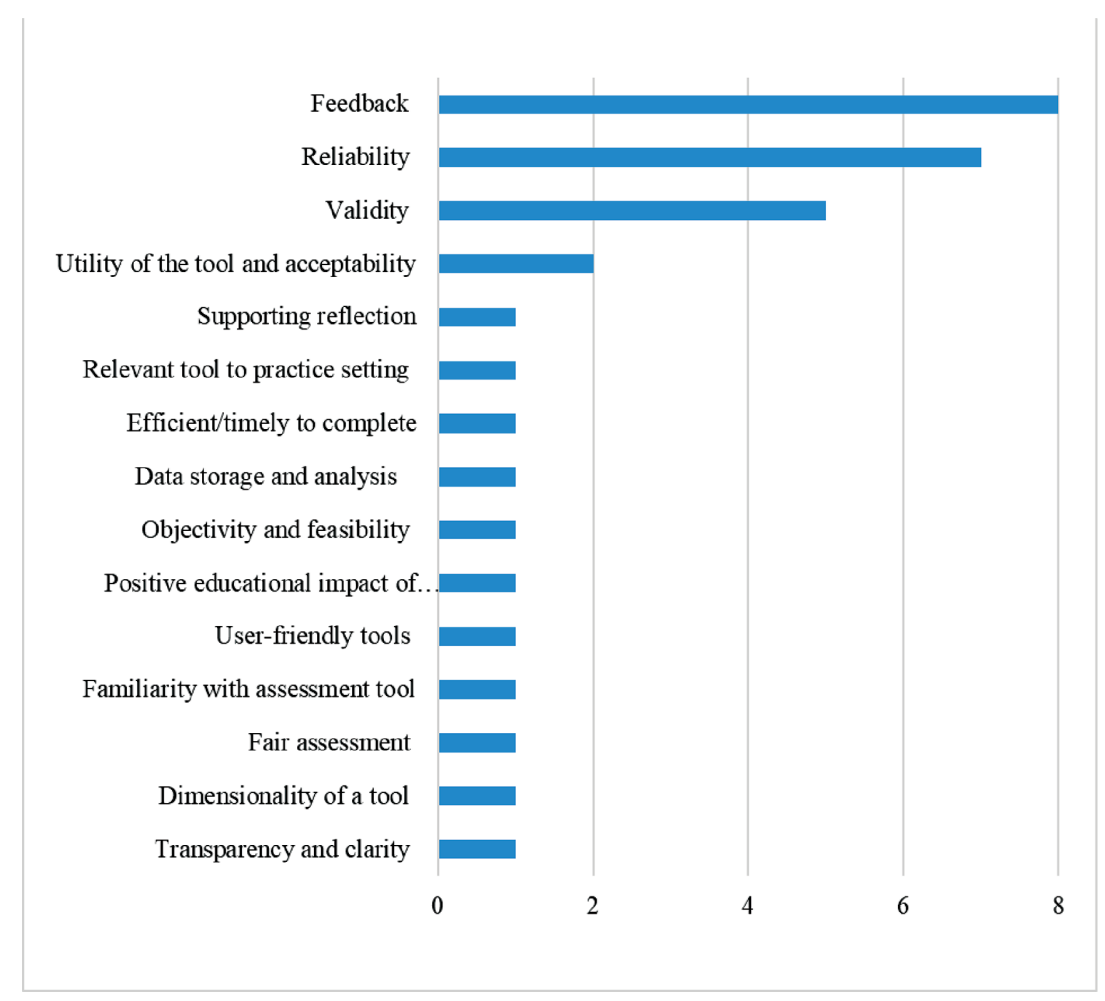

Figure 3. Quality criteria mentioned in the papers included.

ensures clarity and transparency in selecting items for the assessment process. ${ }^{22,49}$ Also, using manikins' functionality and other instruments such as cameras and microphones helps to capture relevant data for storage and reference. ${ }^{39}$ Testing instruments ensures that students and examiners are familiar with the assessment tools before examination ${ }^{45}$ as evident in all the tools that were described in Table 1.

\subsubsection{Examiner-related factors}

Lack of training of examiners, workload, and lack of time makes assessment challenging. ${ }^{22}$ Some examiners also complained about the assessment tools' language being too academic and complicated, lengthy and time-consuming, so they end up skipping some of the problematic sections. ${ }^{45}$ Some examiners have challenges with awarding "excellent" and excellent grades in some of the higher items, such as confidence in decision-making and being innovative, as they believe that may be difficult to achieve in specialist areas. ${ }^{22}$ Some examiners also struggle when they are not well trained, not familiar with the practice setting, not experienced, not confident, and not competent in what is being assessed. ${ }^{22,38,39}$ Therefore, preceptors, mostly examiners, felt prepared and fulfilled after going through a training course. ${ }^{45}$ Nurse 
educators and nurse clinicians appointed as examiners need to be well trained to assess students. ${ }^{22,45}$ Training also prepared examiners to cope with the fear of failing non-performing students. ${ }^{22}$

\subsubsection{Supporting students}

To support students, examinations must be done in a safe environment to reduce anxiety, ${ }^{43}$ and must provide timely support to students when a concern is identified. ${ }^{45}$ In assessing interpersonal skills profiles (ISPs), examiners may need to create an enabling environment such as engagement, confidence in judgment, and welcoming students. ${ }^{22,39}$ Students are believed to be motivated when their good practice is rewarded..$^{22}$ Competencedevelopment Practical Procedures (COPP) helped clarify what to focus on when giving feedback and is used to raise awareness among students on quality in skills training. ${ }^{41}$ Essential areas such as hygiene principles, preparing equipment, being more thorough in what to assess as an observer, and information given to the patient and completing work and documentation were identified.

\subsubsection{Scoring performance}

According to examiners, tools aid in assessing in a safe, effective and proficient manner. ${ }^{13}$ Tools allow the collection of data that can be disseminated later to students and faculty ${ }^{13}$ and can be used as a guide or framework to support examiners' judgments. ${ }^{45}$ The clinical examination results are expressed in different formats such as dichotomous (pass/fail) measurement to an ordinal scale using a five to 20 Likert scale score. ${ }^{44}$ It was reported that students assessed by the most lenient assessors were over seven times more likely to pass than students assessed by the most stringent assessors. ${ }^{16}$ Although language affects performance, for example, indigenous students performed better than international students, the strongest predictor of a student passing their clinical skills assessment was the leniency (doves) and stringency (hawks) of the examiner. ${ }^{16}$

There are other variabilities in the assessment of clinical competence by nurse educators and nurse managers. The age difference between educators and managers also influences the award of marks to students. Numminen ${ }^{37}$ discovered that educators and nurse managers who were $<50$ years of age award lower marks than those over the age of 50 . The finding calls for an investigation of the association between age, expertise groups, and student assessment. Also Oermann et al. ${ }^{39}$ discovered inter-rater disagreement in the assessment of administering medication, managing technology, and equipment. It was found that the inconsistent use of "not applicable" resulted in the inability to judge the performance of students. ${ }^{39}$ In some instances, the software is embedded to forecast a new pass mark to control stringent and lenient examiners. ${ }^{38}$ Fatigue also affects the award of marks. Evaluators needed to break and rest after viewing four videos of students performing clinical competence due to fatigue, indicating there may be the need to extend the duration of the examination. ${ }^{39}$ Novice examiners' rating skills improved after examining eight videos. Also, it was easier to rate outstanding and poor performance than average. ${ }^{39}$ In clinical assessment, students must be allowed to evaluate the examination system, tools, and examiners. ${ }^{47,48}$

\subsubsection{Educational effect}

Assessment of clinical competency skills of students, using various assessment tools, leads to skills improvement. Some students expressed concern over a potential negative stigma among peers for needing and participating in a skills enhancement course. ${ }^{43}$ During peer assessment, students were able to provide feedback to their peers. ${ }^{46}$ Students identified the importance of patient safety and were confident that they could respond to adverse effects toward patients, ${ }^{34}$ while most students were able to competently perform most of the skills assessed on the Creighton Competency Evaluation Instruments (CCEI). ${ }^{39}$ There was no difference in anxiety level when examined using the traditional method or video method on performance. ${ }^{28}$ Formative clinical competency assessment creates an awareness among students to improve their clinical skills. ${ }^{41}$ In effect, examination helps to provide feedback to students and identify their learning needs, towards the provision of remedial activities to enhance learning..$^{45,49}$

\subsection{Quality improvement of the assessment system}

Although most of the articles showed that the current assessment systems were effective (Table 1), there is a need for improvement in some areas. The need for more collaboration between nurse educators and managers could reduce the inter-rater variability and bridge the theory-practice gap. ${ }^{37,45}$ Some competency skills, such as handwashing and communication, need to be assessed exclusively to ensure that students are competent in those areas. ${ }^{30}$ Students must be exposed to skills continuously to improve clinical competency performance, ${ }^{29}$ identifying their learning needs and styles, ${ }^{45}$ increase collaboration, and continuously develop professionally. ${ }^{49}$ Additionally, continuous review of assessment tools, providing space on the sheet for examiners' comments, and including the assessment of ISP in all assessment systems improve the assessment system. ${ }^{22,45}$ 


\section{Discussion}

The results highlighted various aspects of assessment of clinical competency: research output on clinical competency assessment; clinical competency assessment tools in use; criteria for quality clinical competency assessment; the management of clinical competency assessment system; and quality improvement of the examination system.

There was only one study included from the African context. The lack of research on clinical competency assessment in the sub-region may lead to practitioners using evidence from a different context to guide their assessment systems. This phenomenon, if not handled cautiously, may result in ineffective, Eurocentric systems that are not responsive to the SSA context. Previous reviews $s^{2,58}$ found that there is a paucity of nursing and midwifery education research in SSA. It is therefore essential for research on clinical competency assessment from Europe and other regions to be contextualized before guiding practice in SSA. ${ }^{19}$

There are several tools for the assessment of various aspects of clinical competency. Almost all the tools that were used in the studies were validated (Table 2). They are publicly available to guide teaching and practice, which is important in summative assessment as the students and the educators can identify the expectations of the assessment system and prepare accordingly. ${ }^{44,45}$ This helps to bridge the theory-practice gap. Available tools allow students to engage in peer assessment, which is beneficial to them. ${ }^{46}$

A good assessment system must meet some quality criteria. It must: be fairly objective, measure what it is set to measure; produce the same result if it is conducted under similar conditions; be applicable within the context for which it is developed; be acceptable to the stakeholders within the context; be transparent and clear; result in improvement in teaching, learning and practice; and provide feedback to the stakeholders for quality improvement purpose. Any assessment system that is devoid of these qualities will be fraught with biases and unfairness, which will, in turn, lead to licensing of incompetent practitioners or denying competent practitioners license to practice with its associated risk to society. ${ }^{15}$

Just like every functional and effective system, clinical competency assessment systems must be thoroughly planned, developed, and pilot tested before implementation. This ensures that the recipients of the products or outcomes of the system are satisfied with it. The tools used for every assessment system must be validated. Validation of tools gives students confidence in the assessment system. It also ensures the validity and reliability of the assessment. Training of the examiners is essential in ensuring the applicability and reliability of the assessment system and should include the award of marks and the provision of a safe and conducive examination environment. This is observed through their confidence, good inter-rater reliability, and the students' satisfaction. An incompetent examiner risks the introduction of bias which hampers the quality of the assessment system. ${ }^{16}$ In selecting examiners, consideration must be given to the age category and competency skills to be assessed as it affects the outcomes of the examination. ${ }^{37}$

Feedback is essential in the continuous improvement of an examination system. Students, examiners, and educators must be allowed to evaluate the examination system and the tools used to provide empirical evidence on which quality improvement could be based. Feedback from the examination body in terms of publishing anonymized examination results also provides the institutions and students data for quality improvement. Feedback on various aspects of the care provided by students during formative clinical competency assessment provides data on learning needs, remediation, and improvement in clinical competency.

\section{Conclusions}

A good assessment system must be valid, reliable, transparent, feasible, must provide feedback, continually improve, must be fair, must be objective, and have an educational impact. Clinical competency assessment systems must be developed on sound empirical evidence, pilot tested, and involve thorough training and evaluation of the examiners. Continuous evaluation of the assessment system is also essential in ensuring the quality and relevance of an assessment system. The paucity of clinical competency assessment research in sub-Saharan Africa may lead to benchmarking assessment systems on research conducted outside the context. Sub-Saharan Africa has a set of circumstances that demand a context-specific clinical competency assessment framework to guide clinical competency assessment in the sub-region.

The study presents a review and synthesis of empirical evidence on clinical nursing competency assessment globally. The findings highlighted critical areas that need attention in designing and improving clinical competency assessments systems especially in licensing examinations, which serve as the bridge between training and qualification as a nurse in many countries globally. The findings in this study, if applied, will assist in ensuring that only competent nurses are license to practice nursing, thereby protecting the public against malpractices. 


\section{Acknowledgment}

We would like to acknowledge Professor Gerda Reitsma and the centre for Health Professions Education, NorthWest University for their support during the manuscript writing phase. Special thanks to Dr. Kwame AnimBoamah for his support during the study.

\section{References}

1. International Council of Nurses (ICN). ICN Regulation Series ICN Framework of Competencies for the Nurse Specialist; 2009. https://siga-fsia.ch/files/ user_upload/08_ICN_Framework_for_the_nurse_ specialist.pdf. Accessed Februray 20, 2021.

2. Kpodo CJ, Thurling $\mathrm{CH}$, Armstrong SJ. Best clinical nursing education practices in sub - Saharan Africa: an integrative literature review. In: 27th International Nursing Research Congress 78890. Sigma Theta Tau International; 2016.

3. Nayeri ND, Jafarpour H. Relationship between clinical competence and motivation needs of nurses based on the McClelland theory. Nurs Pract Today. 2014;1:86-92.

4. Rahimaghaee F, Mozdbar R. Cultural intelligence and its relation with professional competency in nurses. Nurs Pract Today. 2017;4:115-124.

5. Christmals CD, Gross JJ. An analysis of the introduction of digital nursing licensing examination in Ghana. Int J Caring Sci. 2019;12:1892-1897.

6. Shin SJ. Kim YK, Suh S-R, Jung DY, Kim Y, Yim MK. Perception survey on the introduction of clinical performance examination as part of the national nursing licensing examination in Korea. J Educ Eval Health Prof. 2017;14:26.

7. Hou J, Chen S, Sabharwal S, Fan V, Yan N, Wang W. Comparison of RN licensure examination: China and the United States. Int J Nurs Sci. 2019;6:111-116.

8. Clarke M. Framework for Building an Effective Student Assessment System. The World Bank Group; 2011. http://scholar.google.co.za/scholar $? q=$ Framework+for+Building+an+Effective + Stud ent+Assessment+System\&hl=en\&as_sdt=0\&as vis=1\&oi=scholart. Accessed Februray 15, 2021.

9. Terry R, Hing W, Orr R, Milne N. Do coursework summative assessments predict clinical performance? Asystematic review. BMC Med Educ. 2017;17:1-15.

10. Hudges SJ, Quinn FM. Quinn's Principles and Practice of Nurse Education. UK: Cengage Learning EMEA; 2013.

\section{Ethical approval}

Ethical issues are not involved in this paper.

\section{Conflicts of interest}

All contributing authors declare no conflicts of interest.
11. Gulikers JTM, Bastiaens TJ, Kirschner PA. A fivedimensional framework for authentic assessment. Educ Technol Res Dev. 2004;52:67-86.

12. Kennedy S, Chesser-Smyth P. Assessment of undergraduate nursing students from an Irish perspective: decisions and dilemmas? Nurse Educ Pract. 2017;27:95-100.

13. Zasadny MF, Bull RM. Assessing competence in undergraduate nursing students: the Amalgamated Students Assessment in practice model. Nurse Educ Pract. 2015;15:126-133.

14. Alquwez N, Cruz JP, Alshammari F, et al. A multiuniversity assessment of patient safety competence during clinical training among baccalaureate nursing students: a cross-sectional study. J Clin Nurs. 2019;28:1771-1781.

15. Norcini J, Anderson B, Bollela V, et al. Criteria for good assessment: consensus statement and recommendations from the Ottawa 2010 conference. Med Teach. 2011;33:206-214.

16. Daly M, Salamonson Y, Glew PJ, Everett B. Hawks and doves: the influence of nurse assessor stringency and leniency on pass grades in clinical skills assessments. Collegian. 2017;24:449-454.

17. Reljić NM, Lorber M, Vrbnjak D, Sharvin B, Strauss M. Assessment of clinical nursing competencies: literature review. Teach Learn Nurs. 2017. https:// www.intechopen.com/chapters/54200. Accessed February 17, 2021.

18. Tricco AC, Lillie E, Zarin W, et al. PRISMA extension for scoping reviews (PRISMA-ScR): Checklist and explanation. Ann Intern Med. 2018;169:467-473.

19. Christmals CD, Armstrong SJ. The essence, opportunities and threats to Advanced Practice Nursing in Sub-Saharan Africa: a scoping review. Heliyon. 2019;5:1-21.

20. Mendeley. Free Reference Manager \& Citation Generator - Mendeley. Elsevier 1; 2018. https:// www.mendeley.com/reference-management/reference-manager. Accessed February 17, 2021. 
21. Christmals CD, Gross J, Aziato L, Armstrong SJ. The state of nursing research in Ghana: an integrative literature review. SAGE Open Nurs. 2018;4:237796081878382.

22. Meier K, Parker P, Freeth D. Mechanisms that support the assessment of interpersonal skills: a realistic evaluation of the interpersonal skills profile of pre-registration nursing students. J Pract Teach Learn. 2014;12:6-24.

23. De Souza MT, Carvalho R. Integrative review: what is it? How to do it? Revisão Integr. o que é e como fazer. 2010;8:102-107.

24. Sandelowski M, Voils Cl, Leeman J, Crandell JL. Mapping the mixed methods - mixed research synthesis terrain. J Mix Methods Res. 2012;6:317-331.

25. Whittemore $R$, Knafl $K$. The integrative review: updated methodology. $J$ Adv Nurs. 2005;52:546-553.

26. Ahn H, Kim H-Y. Implementation and outcome evaluation of high-fidelity simulation scenarios to integrate cognitive and psychomotor skills for Korean nursing students. Nurse Educ Today. 2015;35:706-711.

27. Prion SK, Gilbert GE, Adamson KA, KardongEdgren S, Quint, S. Development and testing of the quint leveled clinical competency tool. Clin Simul Nurs. 2017;13:106-115.

28. Teixeira CRS, Kusumota L, Pereira MCA, et al. Anxiety and performance of nursing students in regard to assessment via clinical simulations in the classroom versus filmed assessments. Investig Educ. Enferm. 2014;32:270-279.

29. Alamri MS, Almazan JU. Barriers of physical assessment skills among nursing students in Arab Peninsula. Int J Health Sci (Qassim). 2018;12:58-66.

30. Safabakhsh L, Arbabshastan ME, Sharifi S, Arbabisarjou A. Clinical competence assessment in pre-registration nursing. Der Pharm Lett. 2016;8:82-85.

31. Gurková E, Žiaková K, Zanovitová M, Cibríkova S, Hudáková A. Assessment of nursing student performance in clinical settings - usefulness of rating scales for summative evaluation. Cent Eur J Nurs Midwifery. 2018;9:791-798.

32. Iglesias-Parra MR, García-Guerrero A, GarcíaMayor S, Kaknani-Uttumchandani S., LeónCampos Á, Morales-Asencio JM. Design of a competency evaluation model for clinical nursing practicum, based on standardized language systems: psychometric validation study. J Nurs Scholarship. 2015;4:371-376.

33. Kajander-Unkuri S, Leino-Kilpi $H$, Katajisto J, et al. Congruence between graduating nursing students' self-assessments and mentors' assessments of students' nurse competence. Collegian. 2016;23:303-312.

34. Langari MNM, Tella S, Smith N-J, Ma H, Turunen $H$. Self-assessment of patient safety competence: a questionnaire survey of final year British and finnish pre-registration nursing students. Int J Caring Sci. 2017;10:1212-1224.

35. Maciá-Soler ML, González Chordá V, Medina PS, Tudela DM, Gasch AC, Cortés MIO. Level of involvement of clinical nurses in the evaluation of competence of nursing students. Investig Educ Enferm. 2018;32:461-470.

36. Murray K, McKenzie K, Kelleher M. The evaluation of a framework for measuring the non-technical ward round skills of final year nursing students: an observational study. Nurse Educ Today. 2016;45:87-90.

37. Numminen $O$, Laine $T$, Isoaho $H$, Hupli $M$, LeinoKilpi H, Meretoja R. Do educational outcomes correspond with the requirements of nursing practice: educators' and managers' assessments of novice nurses' professional competence. Scand. J Caring Sci. 2014;28:812-821.

38. Meskell P, Burke E, Kropmans TJB, Byrne E, Setyonugroho W, Kennedy KM. Back to the future : an online OSCE management information system for nursing OSCEs. Nurse Educ Today. 2015;35:1091-1096.

39. Oermann MH, Kardong-Edgren S, Rizzolo MA. Towards an evidence-based methodology for high-stakes evaluation of nursing students' clinical performance using simulation. Teach Learn Nurs. 2016;11:133-137.

40. Ossenberg C, Dalton M, Henderson A. Validation of the Australian Nursing Standards Assessment Tool (ANSAT): a pilot study. Nurse Educ Today. 2016;36:23-30.

41. Solheim E, Plathe HS, Eide H. Nursing students' evaluation of a new feedback and reflection tool for use in high-fidelity simulation - formative assessment of clinical skills. A descriptive quantitative research design. Nurse Educ Pract. 2017;27:114-120.

42. Cassidy S, Coffey M, Murphy F. 'Seeking authorization': a grounded theory exploration of mentors' experiences of assessing nursing students on the borderline of achievement of competence in clinical practice. J Adv Nurs. 2017;73:2167-2178.

43. Ochylski D, Aebersold M, Kuebric MB. Multidimensional evaluation of simulation-based course to enhance prelicensure nursing students' clinical skills. Nurse Educ. 2017;42:313-315. 
44. Tommasini C, Dobrowolska B, Zarzycka D, et al. Competence evaluation processes for nursing students abroad: Findings from an international case study. Nurse Educ Today. 2017;51:41-47.

45. Burke E, Kelly M, Byrne E, Chiardha TU, Mc Nicholas M, Montgomery A. Preceptors' experiences of using a competence assessment tool to assess undergraduate nursing students. Nurse Educ Pract. 2016;17:8-14.

46. Lai CY. Training nursing students' communication skills with online video peer assessment. Comput Educ. 2016;97:21-30.

47. Márquez-Hernández VV, Gutiérrez-Puertas L, Granados-Gámez G, Rodríguez-García MC, Gutiérrez-Puertas V, Aguilera-Manrique G. Development of a web-based tool to evaluate competences of nursing students through the assessment of their clinical skills. Nurse Educ Today. 2019;73:1-6.

48. Imanipour M, Jalili M. Development of a comprehensive clinical performance assessment system for nursing students: a programmatic approach. Japan J Nurs Sci. 2016;13:46-54.

49. Wu XV, Enskär K, Pua LH, Heng DGN, Wang W. Development and psychometric testing of Holistic Clinical Assessment Tool (HCAT) for undergraduate nursing students. BMC Med Educ. 2016;16:1-9.

50. Joanna Briggs Institute. Critical appraisal tools. Joanna Briggs Institute; 2020. https://joannabriggs. org/critical-appraisal-tools. Accessesd Februray 16 2021.

51. Oetker-Black SL, Kreye J. Global psychometric evaluation of the clinical skills self-efficacy scale in Moshi, Tanzania. Nurs Educ Perspect. 2015;36:163-166.

52. Tanner CA. The next transformation: clinical education. J Nurs Educ. 2006;45:99-100.

53. Klakovich MD, Dela Cruz FA. Validating the interpersonal communication assessment scale. J Prof Nurs. 2006;22:60-67.

54. Ginsburg L, Castel E, Tregunno D, Norton PG. The H-PEPSS: an instrument to measure health professionals' perceptions of patient safety competence at entry into practice. BMJ Qual Safety. 2012;21:676-684.

55. Khanghahi ME, Ebadi F, Azar F. Direct observation of procedural skills (DOPS) evaluation method: systematic review of evidence. Med J Islam Repub Iran. 2018;32:45.

56. Pires SMP, Monteiro SOM, Pereira AMS, Stocker JNM, de Mascarenhas Chaló D, de Oliveira Pinho de Melo EM, et al. Non-technical skills assessment scale in nursing: Construction, development and validation. Rev Lat Am Enfermagem. 2018;26:3042.

57. Hayden J, Keegan M, Kardong-Edgren S, Smiley RA. Reliability and validity testing of the creighton competency evaluation instrument for use in the ncsbn national simulation study. Nurs Educ Perspect. 2014;35:244-252.

58. Sun C, Larson E. Clinical nursing and midwifery research in African countries: a scoping review. Int J Nurs Stud. 2015;52:1011-1016.

59. Oetker-Black SL, Kreye J, Underwood S, Price A, DeMetro N. Psychometric evaluation of the Clinical Skills Self-Efficacy Scale. Nurs Educ Perspect. 2014;35:253-256. 